\title{
Regulation of interleukin-1 $\beta$ and interleukin-1 $\beta$ inhibitor release by human airway epithelial cells
}

\author{
Y. Yang, W. Bin, M.O. Aksoy, S.G. Kelsen
}

Regulation of interleukin-1 $\beta$ and interleukin-1 $\beta$ inhibitor release by human airway epithelial cells. Y. Yang, W. Bin, M.O. Aksoy, S. G. Kelsen. (C)ERS Journals Ltd 2004. ABSTRACT: In asthma, human airway epithelial cells (HAECs) regulate the intensity of mucosal inflammation, in part, by releasing the pro-inflammatory cytokine

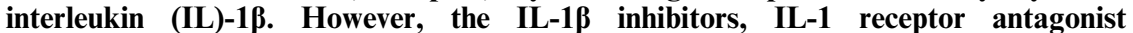
(IL-1RA) and soluble IL-1 receptor type II (sIL-1RII), regulate IL-1 $\beta$ bioactivity. In order to better understand the control of IL-1 $\beta$ activity in the airway mucosa, the role(s) of tumour necrosis factor (TNF)- $\alpha$, cyclic adenosine monophosphate (cAMP) and cyclic guanosine monophosphate (cGMP) in the release of IL-1 $\beta$ and its inhibitors by cultured HAECs were examined.

HAECs were treated with TNF- $\alpha\left(2-200 \mathrm{ng} \cdot \mathrm{mL}^{-1}\right)$, dibutyryl cAMP $(0.01-1 \mathrm{mM})$, 8-bromo-cGMP (0.01-1 mM) or vehicle for $24 \mathrm{~h}$, and cytokine levels in the HAECconditioned medium were measured by enzyme-linked immunosorbent assay.

HAECs produced IL-1 $\beta$, IL-1RA and sIL-1RII constitutively, but the inhibitor concentrations greatly exceeded that of IL-1 $\beta$ (by $\sim 100$ - and $\sim 550$-fold, respectively). TNF- $\alpha$ dose-dependently increased the levels of all IL-1 $\beta$ cytokine family members. However, over the range of TNF- $\alpha$ concentrations studied, IL-1 $\beta$ concentration increased more than those of its inhibitors. cAMP increased constitutive and TNF- $\alpha$ stimulated IL-1 $\beta$ release but reduced that of sIL-1RII. In contrast, cGMP had no effect on IL-1ß but reduced IL-1RA and SIL-1RII release.

Under basal conditions, the disproportionate release of inhibitors relative to

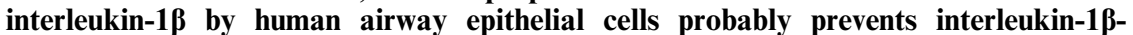
mediated biological effects. Tumour necrosis factor- $\alpha$, cyclic adenosine monophosphate and cyclic guanosine monophosphate may potentiate mucosal inflammation by increasing interleukin-1 $\beta$ levels relative to those of its inhibitors in the airway mucosa. Eur Respir J 2004; 24: 360-366.
Division of Pulmonary, Allergy and Critical Care Medicine, Dept of Medicine, Temple University School of Medicine, Philadelphia, PA, USA.

Correspondence: S.G. Kelsen

761 Parkinson Pavilion

Temple University Hospital

3401 N. Broad St.

Philadelphia, PA 19140

USA

Fax: 12157071481

E-mail: kelsen@temple.edu

Keywords: Airway inflammation

asthma

cytokines

Received: August 42003

Accepted after revision: March 292004

This study was supported, in part, by National Institutes of Health (Bethesda, MD, USA) grant number R01 HL52700-04.
Human airway epithelial cells (HAECs) release a variety of cytokines and chemokines which regulate the intensity of mucosal inflammation [1, 2]. For example, the proinflammatory cytokine, interleukin (IL)- $1 \beta$, which is produced by HAECs, is thought to play an important role in the pathogenesis of asthma [2-9]. IL-1 $\beta$ levels are increased in bronchoalveolar lavage fluid in asthma and these levels correlate with the severity of airway dysfunction [3, 4]. Furthermore, IL-1 $\beta$ immunoreactivity is increased in tracheobronchial epithelial cells in asthmatic compared to normal subjects [5].

The mechanism(s) by which IL-1 $\beta$ produced by HAECs alters airway structure and function in asthma are relatively well understood. For example, IL-1 $\beta$-induced release of cytokines (e.g. regulated on activation, normal $\mathrm{T}$-cell expressed and secreted, granulocyte-macrophage colony-stimulating factor, eotaxin, monocyte chemotactic peptide-4, IL-5, etc.) from HAECs augments eosinophil chemotaxis, survival and activation [9-11]. In eosinophils, IL-1 $\beta$ induces release of IL-9, the T-cell and mast cell growth factor, which induces airway eosinophilia, airway hyperreactivity and goblet cell metaplasia. Moreover, IL-1 $\beta$ stimulates release of fibroblast growth factors (e.g. platelet-derived growth factor) by HAECs, which enhance fibroblast proliferation and collagen synthesis, thereby contributing to airway remodelling [9, 12]. Finally, IL-1 $\beta$ impairs cyclic adenosine monophosphate
(cAMP) production in HAECs in response to $\beta_{2}$-adrenergic agonists, thereby impairing mucociliary clearance [13].

In contrast to the considerable knowledge regarding the biological effects of IL- $1 \beta$ produced by HAECs, the regulation of IL-1 $\beta$ release and bioactivity is poorly understood. Work in other tissues/cell types indicates that IL-1 $\beta$ bioactivity is closely regulated by a complex system of response modifiers, including a receptor antagonist (IL-1 receptor antagonist (IL-1RA)), which binds to but does not activate the receptor, a membrane-bound decoy receptor (the type II receptor), and soluble forms of the two IL receptors (sIL-1RI and sIL-1RII) [8, 9].

Studies in nonrespiratory cells (e.g. blood monocytes and peritoneal macrophages) suggest that IL-1 $\beta$ activity in the airway may be affected by several factors relevant to asthma and chronic obstructive pulmonary disease (COPD). In monocytes and macrophages, extracellular release of members of the IL-1 $\beta$ cytokine family is controlled by the proinflammatory cytokine, tumour necrosis factor (TNF)- $\alpha$, and cyclic nucleotides (e.g. cAMP) [14, 15]. In asthma and COPD, TNF- $\alpha$ levels in the airway are increased and correlate with the severity of airway obstruction [16, 17]. In both diseases, $\beta_{2}$-adrenergic agonist bronchodilators and theophylline increase intracellular cAMP levels. Finally, increases in airway nitric oxide levels in asthma may increase cyclic guanosine monophosphate (cGMP) levels by activating 
guanylyl cyclase. Accordingly, it was hypothesised that release of IL-1 $\beta$ and its family of inhibitors by HAECs is regulated by TNF- $\alpha$ and changes in intracellular cAMP and cGMP levels. This hypothesis was tested in cultured HAECs by examining the effects of TNF- $\alpha$, cAMP and cGMP on the release of IL-1 $\beta$, IL-1RA and sIL-1RII into the cell culture medium.

\section{Materials and methods}

\section{Cell culture and stimulation}

Experiments were performed using the HAEC line 16-HBE. Cells were cultured in Dulbecco modified Eagle medium (Biosource, Rockville, MD, USA) supplemented with $10 \%$ foetal bovine serum (Sigma, St Louis, MO, USA), penicillin $\left(100 \mathrm{U} \cdot \mathrm{mL}^{-1}\right)$ and streptomycin $\left(100 \mathrm{mg} \cdot \mathrm{mL}^{-1}\right)$ in $100-\mathrm{mm}-$ diameter tissue culture dishes in an atmosphere of $5 \%$ carbon dioxide $/ 95 \%$ air at $37^{\circ} \mathrm{C}$ until confluent. Dishes were precoated with type VI human placental collagen (Sigma). In three experiments, primary cultures of normal human primary epithelial cells (NHBEs; Cambrex Bioscience, Walkersville, MD, USA) were studied. NHBEs were grown in collagencoated, six-well plates in bronchial epithelial cell basal medium (Cambrex Bioscience) enriched with $52 \mu \mathrm{g} \cdot \mathrm{mL}^{-1}$ bovine pituitary extract, $0.5 \mu \mathrm{g} \cdot \mathrm{mL}^{-1}$ hydrocortisone, $0.5 \mathrm{ng} \cdot \mathrm{mL}^{-1}$ epidermal growth factor, $0.5 \mu \mathrm{g} \cdot \mathrm{mL}^{-1}$ adrenalin, $10 \mu \mathrm{g} \cdot \mathrm{mL}^{-1}$ transferrin, $5 \mu \mathrm{g} \cdot \mathrm{mL}^{-1}$ insulin, $6.5 \mathrm{ng} \cdot \mathrm{mL}^{-1}$ triiodothyronine and $0.1 \mathrm{ng} \cdot \mathrm{mL}^{-1}$ retinoic acid.

At confluence, cells were treated with TNF- $\alpha$, the cellpermeable form of cAMP, dibutyryl cAMP, or the cellpermeable form of cGMP, 8-bromo-cGMP (all from Sigma). Vehicle-treated cells $(0.1 \%$ bovine serum albumin in phosphatebuffered saline or dimethyl sulphoxide) served as controls. In initial time course experiments, cells were treated with TNF- $\alpha$ $\left(20 \mathrm{ng} \cdot \mathrm{mL}^{-1}\right)$ for $2-30 \mathrm{~h}$. The maximum concentrations of all three cytokines occurred at $24 \mathrm{~h}$. Thereafter, cells were treated for $24 \mathrm{~h}$ with TNF- $\alpha\left(2-200 \mathrm{ng} \cdot \mathrm{mL}^{-1}\right)$, dibutyryl cAMP (0.01-1 mM), or 8-bromo-cGMP $(0.01-1 \mathrm{mM})$. In separate experiments, the interactive effects of TNF- $\alpha$ and the cyclic nucleotides were determined. In these experiments, cells were treated with TNF- $\alpha\left(20 \mathrm{ng} \cdot \mathrm{mL}^{-1}\right)$ alone or in combination with either dibutyryl cAMP $(1 \mathrm{mM})$ or 8-bromo-cGMP $(1 \mathrm{mM})$. Finally, the role of protein kinase A (PKA) and protein kinase $\mathrm{G}(\mathrm{PKG})$ pathways in mediating the effects of dibutyryl cAMP and 8-bromo-cGMP were examined using the PKA and PKG inhibitors, KT 5720 and KT 5823 (Calbiochem, La Jolla, CA, USA; $0.1-10 \mu \mathrm{M}$ ), respectively. Inhibitors were added $1 \mathrm{~h}$ before TNF- $\alpha$ alone or in combination.

After treatment, the cell-conditioned medium was collected and concentrated 20 -fold by centrifugation in Centricon Plus20 filters (Millipore, Billerica, MA, USA) for 30-90 min at $2,800 \times g$ at $4{ }^{\circ} \mathrm{C}$. Samples were stored at $-20^{\circ} \mathrm{C}$ prior to assay. After the medium was collected, cells were detached using $0.05 \%$ trypsin and $0.53 \mathrm{mM}$ ethylenediamine tetra-acetic acid (EDTA) in Hank's balanced salt solution and viability assessed by trypan blue $(0.4 \%)$ exclusion. In all experiments, epithelial cell viability was $>90 \%$.

\section{Cytokine assays}

IL-1 $\beta$, IL-1RA and sIL-1RII levels in the epithelial cellconditioned medium were measured by solid- phase sandwich enzyme-linked immunosorbent assay in 96-well microtitre plates.
IL-1 $\beta$ concentration was measured using two different mouse antihuman monoclonal antibodies (immunoglobulin (Ig) G1) directed against IL-1 $\beta$ (Biosource International, Camarillo, CA, USA). A separate biotin-conjugated mouse monoclonal antibody (IgG1 $\kappa$ chain) $\left(0.2 \mu \mathrm{g} \cdot \mathrm{mL}^{-1}\right.$; Biosource International) was used for detection. The antigen/antibody conjugate was detected colorimetrically by the addition of horseradish peroxidase (HRP)-conjugated streptavidin followed by tetramethylbenzidine (TMB) as substrate. Colour intensity at $450 \mathrm{~nm}$ was measured using a microplate reader (Bio-Rad model 550; Bio-Rad, Hercules, CA, USA). Samples were assayed in triplicate. Concentrations in sample media were calculated by interpolation from a standard curve using recombinant human IL-1 $\beta$ as the standard. The threshold of detection in the IL- $1 \beta$ assay was $<0.19 \mathrm{pg} \cdot \mathrm{mL}^{-1}$.

IL-1RA concentration was measured using a single mouse antihuman monoclonal antibody (IgG1) directed against IL-1RA and the same biotin/streptavidin detection system as described above for IL-1 $\beta$. The antibody used to measure IL-1RA recognised all three isoforms of IL-1RA. The threshold of detection in the IL-1RA assay was $\sim 4 \mathrm{pg} \cdot \mathrm{mL}^{-1}$.

sIL-1RII concentration in epithelial cell-conditioned medium was measured using a mouse antihuman monoclonal antibody directed against sIL-1RII (R\&D Systems, Minneapolis, MN, USA). sIL-1RII rather than sIL-1RI was measured since the type II receptor predominates over the type I receptor in epithelial cells [18, 19], and sIL-1RII exhibits greater affinity for IL-1 $\beta$ than does sIL-RI [20]. A separate HRP-conjugated rabbit polyclonal antibody directed against human sIL-1RII was used for detection of the antigen/ antibody complex (R\&D Systems) and the reaction monitored as described for the IL-1 $\beta$ assay. The threshold of detection in the sIL-1RII assay was $<10 \mathrm{pg} \cdot \mathrm{mL}^{-1}$.

\section{Statistical analysis}

Comparison of mean values in control and experimental groups was performed by paired t-test. In order to normalise for differences in cell responses to the various stimuli, data were also expressed as a percentage of the control value (vehicle-treated cells). TNF- $\alpha$, dibutyryl cAMP, 8-bromocGMP, and PKA and PKG inhibitor dose/response effects on cytokine concentration were assessed by one-way repeated measures analysis of variance (ANOVA). Significance of differences in group mean values was taken at the $p<0.05$ level.

\section{Results}

Cultured 16-HBE cells and primary cultures of HAECs constitutively released IL-1 $\beta$, IL-1RA and sIL-1RII into the medium (table 1). However, the IL-1 $\beta$ level, expressed in terms of molarity, was $\sim 100$-fold lower than that of IL-1RA and $\sim 550$-fold lower than that of sIL-1RII.

Table 1.-Constitutive release of interleukin (IL)-1 $\beta$ and its inhibitors by $16-\mathrm{HBE}$ cells

\begin{tabular}{lcc}
\hline & \multicolumn{2}{c}{ Concentration in medium } \\
\cline { 2 - 3 } & $\mathrm{pg} \cdot \mathrm{mL}^{-1}$ & $\mathrm{fM}$ \\
\hline IL-1 $\beta$ & $0.07 \pm 0.01$ & $4.1 \pm 0.6$ \\
IL-1RA & $7.1 \pm 1.0$ & $410 \pm 57$ \\
sIL-1RII & $102.8 \pm 16.9$ & $2280 \pm 376$ \\
\hline
\end{tabular}

Data are presented as mean \pm SEM. IL-1RA: IL-1 receptor antagonist; sIL-1RII: soluble IL-1 receptor type II. 


\section{Effects of TNF- $\alpha$}

TNF- $\alpha\left(2-200 \mathrm{ng} \cdot \mathrm{mL}^{-1}\right)$ caused an increase in IL-1 $\beta$, IL-1RA and sIL-1RII levels over $24 \mathrm{~h}$ (all $\mathrm{p}<0.001$ (ANOVA)) (fig. 1). However, the nature and magnitude of the response of the three IL- $1 \beta$ cytokine family members to TNF- $\alpha$ differed. For example, increases in IL-1 $\beta$ were progressive over the entire range of TNF- $\alpha$ concentrations, whereas increases in IL-1RA and sIL-1RII reached a plateau at $20 \mathrm{ng} \cdot \mathrm{mL}^{-1} \mathrm{TNF}-\alpha$. In addition, increases in IL-1 $\beta$ level
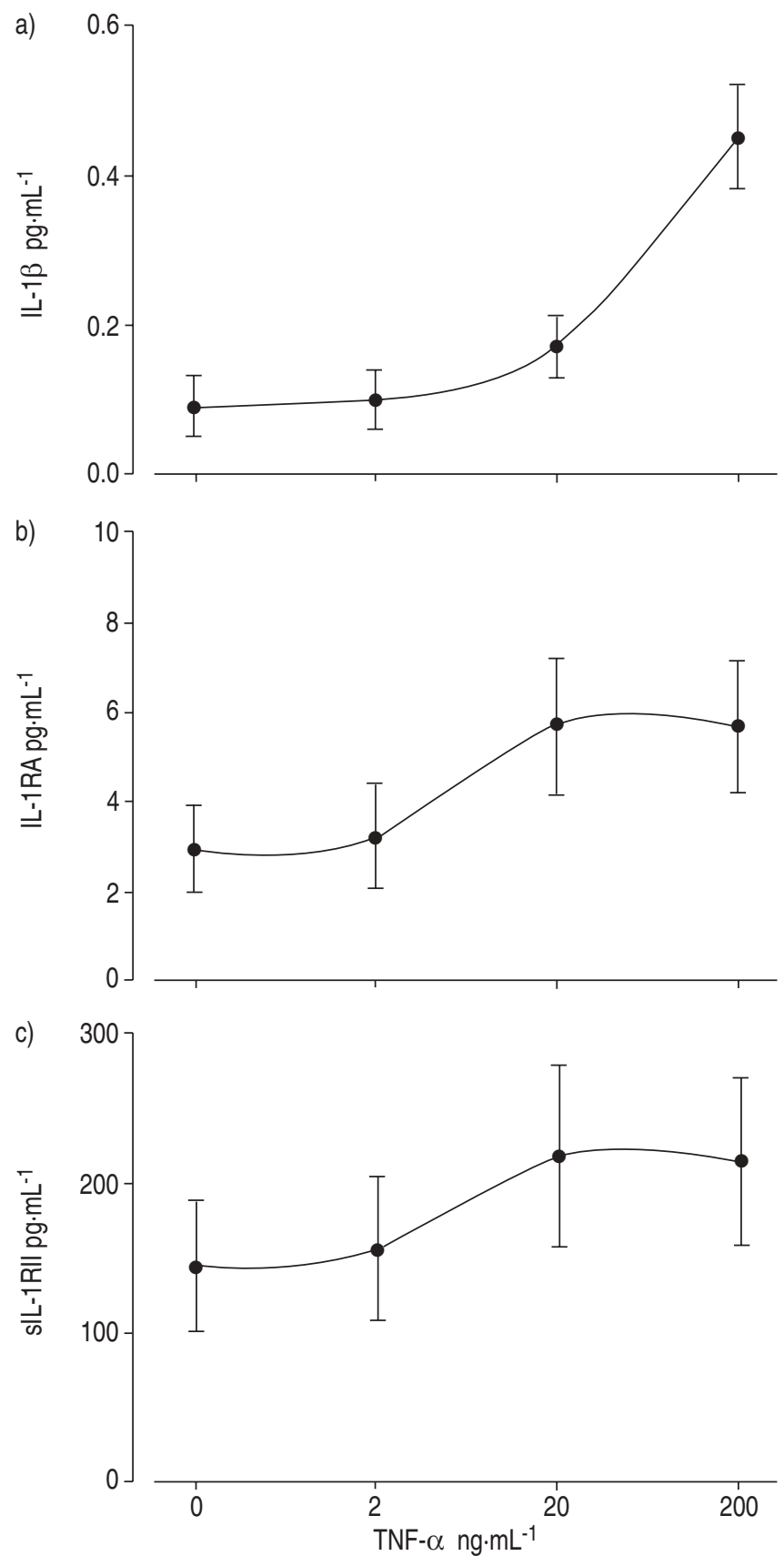

Fig. 1. - Effect of tumour necrosis factor (TNF)- $\alpha$ on a) interleukin (IL)-1 $\beta$, b) IL-1 receptor antagonist (IL-1RA) and c) soluble IL-1 receptor type II (sIL-1RII) release by 16-HBE cells. Data are presented as mean \pm SEM (11 experiments). Levels of all three cytokines at $24 \mathrm{~h}$ were increased by TNF- $\alpha$. However, the relative increases were greater for IL-1 $\beta(\mathrm{p}<0.001)$ than for either IL-1RA $(\mathrm{p}=0.003)$ or sIL-1RII $(\mathrm{p}=0.018)$. were proportionately greater (i.e. $\sim 8$-fold) than those in IL-1RA and sIL-1RII ( 1.4-2-fold).

\section{Effects of cAMP and cGMP}

Dibutyryl cAMP $(1 \mathrm{mM})$ treatment increased IL-1 $\beta$ release both alone and in the presence of TNF- $\alpha$ (fig. 2a). Conversely, dibutyryl cAMP had no effect on IL-1RA release but reduced both constitutive and TNF- $\alpha$-induced sIL-1RII release (figs. 3a and 4a).

In contrast to the effects of dibutyryl cAMP, 8-bromocGMP $(1 \mathrm{mM})$ significantly reduced IL-1RA and sIL-1RII release in both the absence and presence of TNF- $\alpha$ (figs. $3 \mathrm{~b}$ and $4 b$ ), but had no effect on IL-1 $\beta$ (fig. $2 b$ ).

The effects of dibutyryl cAMP and 8-bromo-cGMP varied with dose, and were greatest at a concentration of $1 \mathrm{mM}$ (table 2).

Effect of PKA and $G$ inhibitors on responses to dibutyryl cAMP and 8-bromo-cGMP

The PKA inhibitor, KT 5720, abolished the dibutyryl cAMP $(1 \mathrm{mM})$-induced increase in IL-1 $\beta$ release $(\mathrm{p}<0.01)$ but had no effect on inhibition of sIL-1RII release (table 3 ).
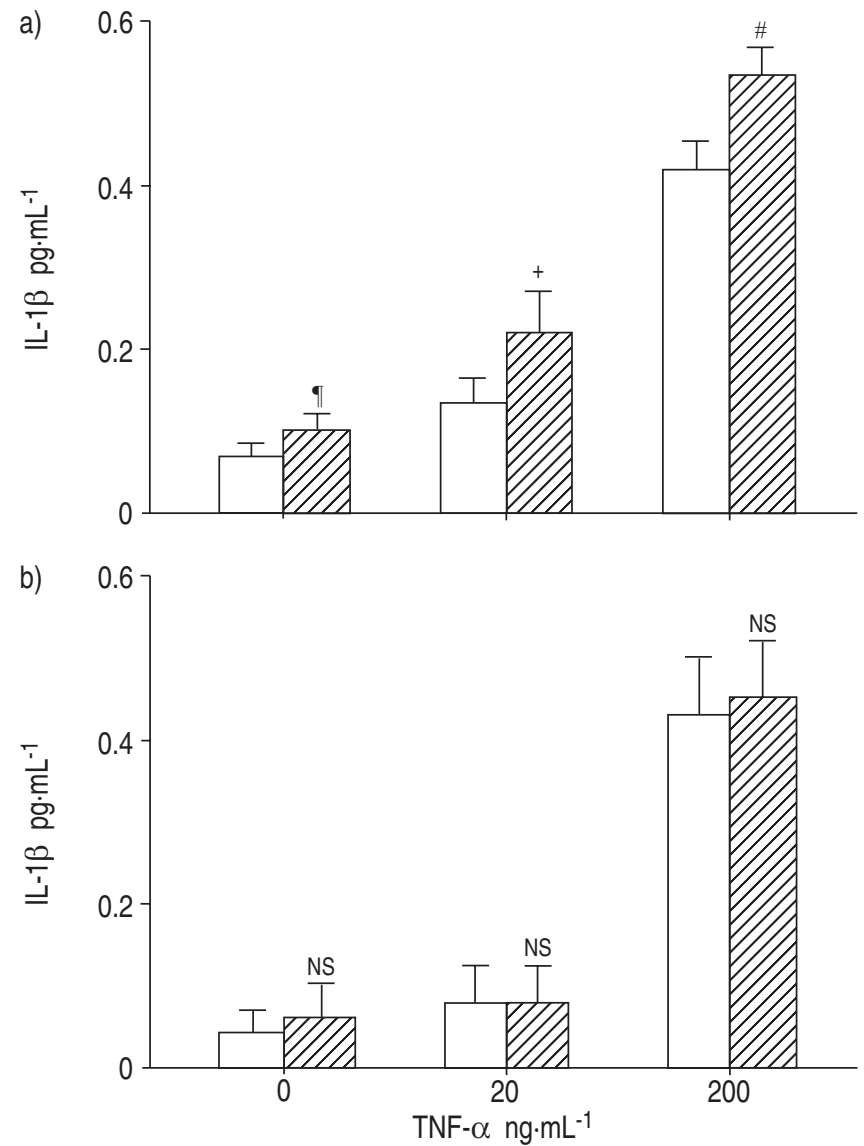

Fig. 2. - Effect of a) dibutyryl cyclic adenosine monophosphate (cAMP) and b) 8-bromo-cyclic guanosine monophosphate (cGMP) on interleukin (IL)-1 $\beta$ release by $16-\mathrm{HBE}$ cells. Cells were incubated for $24 \mathrm{~h}$ in the presence $(\mathbb{Z})$ or absence $(\square)$ of $1 \mathrm{mM}$ cyclic nucleotide. Data are presented as mean \pm SEM. a) 14 experiments; b) 8 experiments. DibutyrylcAMP increased release of IL- $1 \beta$ into the medium and enhanced tumour necrosis factor (TNF)- $\alpha$-induced release. In contrast, 8-bromo-cGMP had no effect on IL-1 $\beta$ release. NS: nonsignificant. ${ }^{\#}: \mathrm{p}<0.03$; ${ }^{\uparrow}$ : $\mathrm{p}<0.003$; ${ }^{+}: \mathrm{p}<0.002$ versus absence of cyclic nucleotide. 

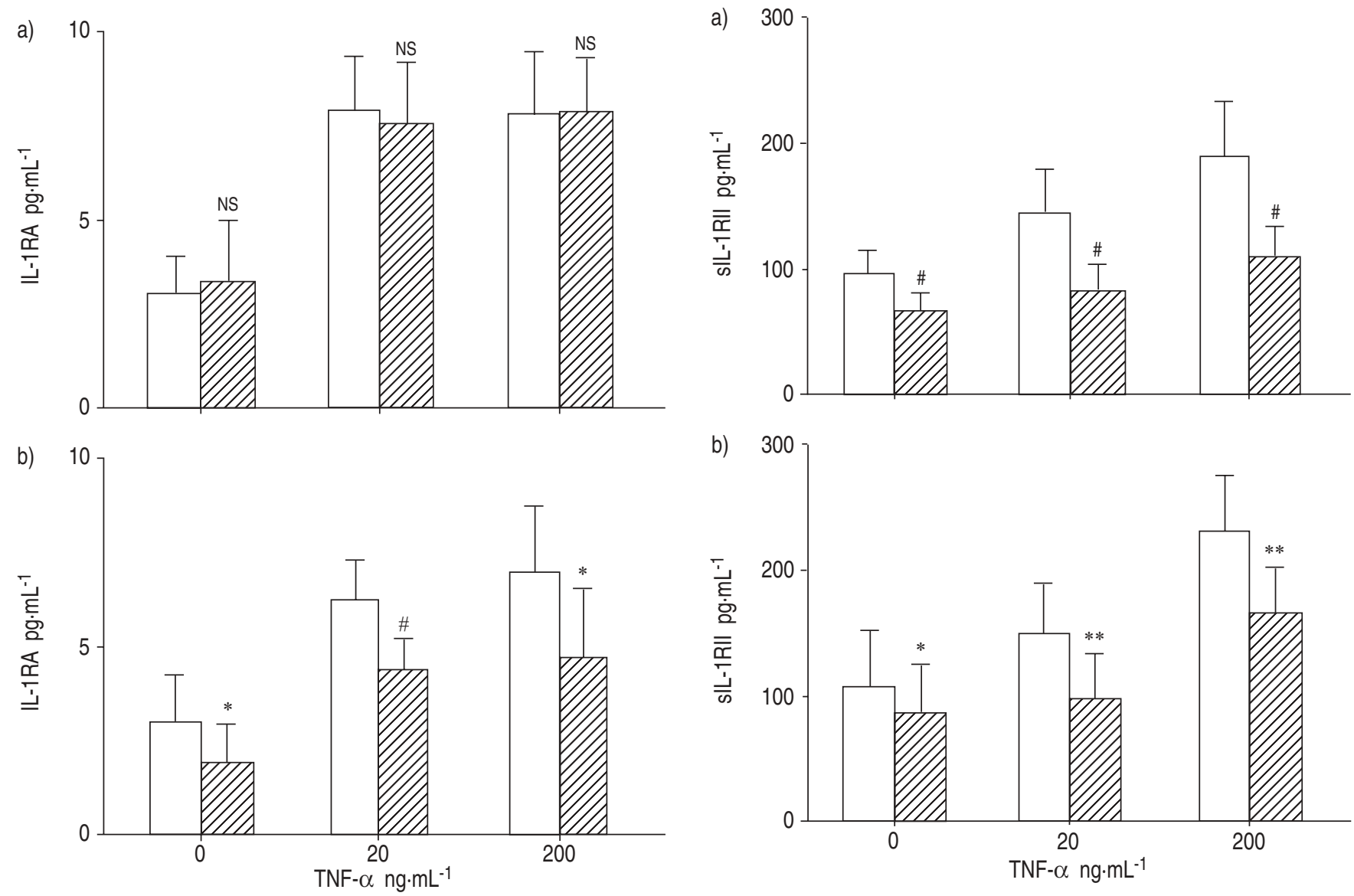

Fig. 3.-Effect of a) dibutyryl cyclic adenosine monophosphate (cAMP) and b) 8-bromo-cyclic guanosine monophosphate (cGMP) on interleukin-1 receptor antagonist (IL-1RA) release by 16-HBE cells. Cells were incubated for $24 \mathrm{~h}$ in the presence $(\mathbb{Z})$ or absence ( $\square)$ of $1 \mathrm{mM}$ cyclic nucleotide. Data are presented as mean \pm SEM. a) 8 experiments and b) 5 experiments. Dibutyryl cAMP had no effect on release of IL-1RA. In contrast, 8-bromo-cGMP significantly inhibited IL-1RA release in the absence of tumour necrosis factor (TNF)- $\alpha$ and antagonised the effect of TNF- $\alpha$. NS: nonsignificant. *: $\mathrm{p}<0.05 ;{ }^{\#}: \mathrm{p}<0.02$ versus absence of cyclic nucleotide.

The PKG inhibitor, KT 5823, reversed the 8-bromocGMP-induced inhibition of IL-1RA release $(\mathrm{p}<0.01)$ but had no effect on inhibition of sIL-1RII release (table 4).

$I L-1 \beta$ cytokine release by primary cultures of $N H B E$ cells: response to $T N F-\alpha$ and $c A M P$

NHBEs produced IL-1 $\beta$, IL-RA and sIL-1RII constitutively (three experiments). It is of interest that IL-1 $\beta$ and IL-RA

Fig. 4.-Effect of a) dibutyryl cyclic adenosine monophosphate (cAMP) and b) 8-bromo-cyclic guanosine monophosphate (cGMP) on soluble interleukin-1 receptor type II (sIL-1RII) release by 16HBE cells. Cells were incubated for $24 \mathrm{~h}$ in the presence $(\mathbb{Z})$ or absence $(\square)$ of $1 \mathrm{mM}$ cyclic nucleotide. Data are presented as mean \pm SEM. a) 12 experiments and b) 8 experiments. Dibutyryl cAMP inhibited release of sIL-1RII into the medium and antagonised tumour necrosis factor (TNF)- $\alpha$-induced release. 8-Bromo-cGMP had similar effects. ${ }^{*}: \mathrm{p}<0.05 ;{ }^{\#}: \mathrm{p}<0.02 ; * *: \mathrm{p}<0.01$ versus absence of cyclic nucleotide.

concentrations $\left(48 \pm 15\right.$ and $527 \pm 76 \mathrm{pg} \cdot \mathrm{mL}^{-1}$, respectively) exceeded those in 16-HBE cells. In contrast, sIL-1RII concentrations $\left(31 \pm 3 \mathrm{pg} \cdot \mathrm{mL}^{-1}\right)$ were lower than those produced by $16-\mathrm{HBE}$ cells.

TNF- $\alpha$ stimulation induced responses by NHBEs which resembled those of 16-HBE cells (three experiments) (fig. 5).

Finally, dibutyryl cAMP ( $1 \mathrm{mM}$ for $24 \mathrm{~h}$ ), given to cells stimulated with $20 \mathrm{ng} \cdot \mathrm{mL}^{-1} \mathrm{TNF}-\alpha$, produced similar effects on IL-1 $\beta$ and sIL-1RII release (three experiments) to those that were observed in 16-HBE cells (data not shown).

Table 2. - Effect of cyclic nucleotides on cytokine release in tumour necrosis factor- $\alpha^{\#}$-stimulated $16-\mathrm{HBE}$ cells

\begin{tabular}{|c|c|c|c|c|c|c|c|c|}
\hline & \multicolumn{4}{|c|}{ Dibutyryl cAMP mM } & \multicolumn{4}{|c|}{ 8-Bromo-cGMP mM } \\
\hline & $0.0^{\oplus}$ & 0.01 & 0.1 & 1.0 & $0.0^{\bullet}$ & 0.01 & 0.1 & 1.0 \\
\hline $\mathrm{IL}-1 \beta \mathrm{pg} \cdot \mathrm{mL}^{-1}$ & $0.127 \pm 0.039$ & $0.135 \pm 0.053$ & $0.154 \pm 0.076$ & $0.189 \pm 0.103^{*}$ & $0.133 \pm 0.045$ & $0.131 \pm 0.033$ & $0.134 \pm 0.029$ & $0.129 \pm 0.035$ \\
\hline IL-1RA pg $\cdot \mathrm{mL}^{-1}$ & $5.7 \pm 0.8$ & $5.9 \pm 0.6$ & $5.5 \pm 0.4$ & $6.1 \pm 0.7$ & $5.2 \pm 0.6$ & $4.4 \pm 0.8$ & $3.8 \pm 0.5$ & $2.9 \pm 0.4^{*}$ \\
\hline $\mathrm{sIL}-1 \mathrm{RII} \mathrm{pg} \cdot \mathrm{mL}^{-1}$ & $172 \pm 45$ & $157 \pm 51$ & $124 \pm 41$ & $89 \pm 32 *$ & $180 \pm 56$ & $171 \pm 63$ & $143 \pm 53$ & $118 \pm 41^{*}$ \\
\hline
\end{tabular}

cAMP: cyclic adenosine monophosphate; cGMP: cyclic guanosine monophosphate; IL: interleukin; IL-1RA: IL-1 receptor antagonist; sIL-1RII: soluble IL-1 receptor type II. \#: $20 \mathrm{ng} \cdot \mathrm{mL}^{-1}$; ${ }^{\uparrow}$ : control. * ${ }^{*}$ : $\mathrm{p}<0.05$ (analysis of variance) 
Table 3. - Effect of KT 5720 on release of interleukin (IL)-1 $\beta$ and soluble IL-1 receptor type II (sIL-1RII) by 16-HBE cells

\begin{tabular}{lcc}
\hline KT $5720 \mu \mathrm{M}$ & IL-1 $\beta$ & sIL-1RII \\
\hline Control \% & 100 & 100 \\
0.0 & $163 \pm 18$ & $52 \pm 6$ \\
0.1 & $135 \pm 25$ & $57 \pm 5$ \\
1.0 & $126 \pm 31$ & $50 \pm 6$ \\
10 & $106 \pm 34$ & $58 \pm 9$ \\
\hline
\end{tabular}

Data are presented as mean \pm SEM percentage of controls. Cells were treated with $20 \mathrm{ng} \cdot \mathrm{mL}^{-1}$ tumour necrosis factor- $\alpha$ alone or in combination with $1 \mathrm{mM}$ dibutyryl cyclic adenosine monophosphate in the presence of the concentration of KT 5720 indicated.

Table 4. - Effect of KT 5823 on release of interleukin (IL)-1 receptor antagonist (IL-1RA) and soluble IL-1 receptor type II (sIL-1RII) by 16-HBE cells

\begin{tabular}{lcc}
\hline KT $5823 \mu \mathrm{M}$ & IL-1RA & sIL-1RII \\
\hline Control \% & 100 & 100 \\
0.0 & $66 \pm 24$ & $50 \pm 7$ \\
0.1 & $106 \pm 19$ & $60 \pm 14$ \\
1.0 & $99 \pm 37$ & $63 \pm 5$ \\
\hline
\end{tabular}

Data are presented as mean \pm SEM percentage of controls. Cells were treated with $20 \mathrm{ng} \cdot \mathrm{mL}^{-1}$ tumour necrosis factor- $\alpha$ alone or in combination with $1 \mathrm{mM} 8$-bromo-cyclic guanosine monophosphate in the presence of the concentration of KT 5823 indicated.

\section{Discussion}

The biological effects of IL- $1 \beta$ in the respiratory tract depend on the concentration of IL- $1 \beta$ relative to those of its several inhibitors [9]. Three forms of IL-1 $\beta$ inhibitor have been described: 1) IL-1RA, which competitively binds the functionally active type I receptor but does not induce a signal; 2) the type II receptor, which has a truncated intracytoplasmic domain that renders it functionally inactive; and 3) soluble forms of the two types of IL-1 receptor (sIL1RI and sIL-1RII), which are shed by activated cells and which reversibly bind IL- $1 \beta$.

Adding to this complexity, three isoforms of IL-1RA have been described (i.e. secretory IL-1RA and two isotypes of intracellular IL-1RA (types I and II)) [9]. Secretory IL-1RA is largely expressed in inflammatory cells such as monocytes and neutrophils [21]. In contrast, both isotypes of intracellular IL-1RA are expressed by keratinocytes and epithelial cells of the tracheobronchial tree, nose, cornea and gastrointestinal tract $[21,22]$. Indeed, in HAECs, intracellular IL-1RA is secreted as well as retained intracellularly [22]. It is of note that the antibody used in the present study detected all three isoforms of IL-1RA.

On cell activation, both IL-1 receptor types are cleaved from the cell surface to generate soluble forms which reversibly bind and inactivate IL-1 $\beta$ [18]. It is of interest that, in epithelial cells, the decoy type II receptors outnumber type I receptors [18, 19]. Moreover, sIL-1RII has greater affinity for IL- $1 \beta$ than for IL-1RA and inhibits IL-1 $\beta$ more potently than does sIL-1RI [20]. As a result, in the airway epithelium, sIL-1RII is probably the functionally more important of the two soluble receptors.

To the present authors' knowledge, the present experiments are the first to simultaneously examine release of IL-1 $\beta$ and its major inhibitors by HAECs. Moreover, for the first time, the release by HAECs of sIL-1RII, an important inhibitor of IL-1 $\beta$, is described. The results of the present study indicate that HAECs constitutively release IL-1 $\beta$, IL-1RA and sIL1RII. However, the concentrations of IL-1RA and sIL-1RII
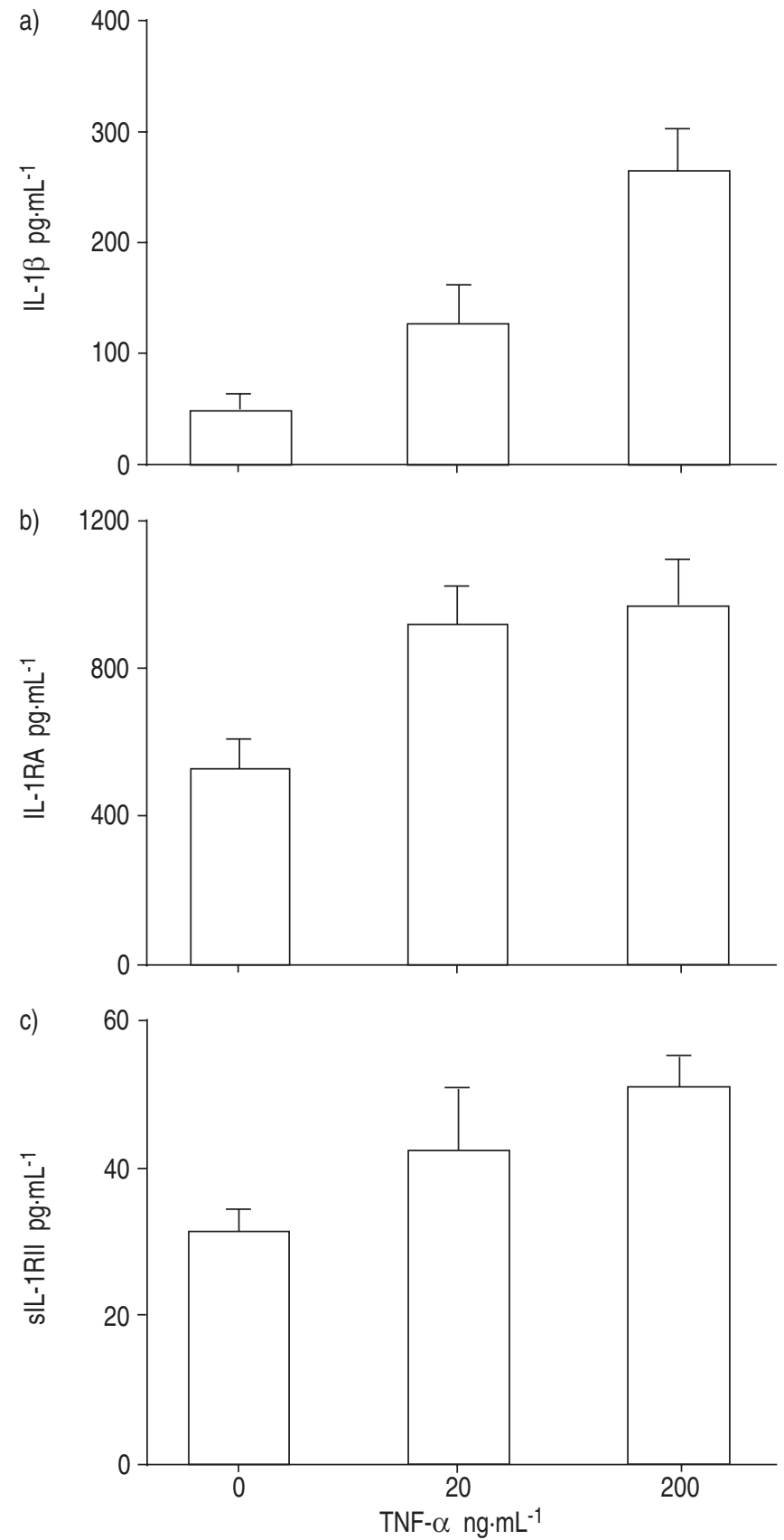

Fig. 5.-Effect of tumour necrosis factor- $\alpha$ (TNF- $\alpha)$ on a) interleukin (IL)-1 $\beta$, b) IL-1 receptor antagonist (IL-1RA) and c) soluble IL-1 receptor type II (sIL-1RII) release by primary cultures of normal human bronchial epithelial cells. Data are presented as mean \pm SEM ( 3 experiments).

produced constitutively are far greater than that of IL- $1 \beta$ in both 16-HBE cells and NHBEs.

HAECs make an important contribution to the pathogenesis of mucosal inflammation, in part by producing IL-1 $\beta$. The results of the present study suggest that, under basal conditions, the greater concentrations of IL-1RA and sIL1 RII relative to IL-1 $\beta$ present in the extracellular space of airway epithelial cells should have the effect of inactivating IL-1 $\beta$. Supporting this concept is the observation by COULTER et al. [23] that a 10-100-fold molar excess of IL1RA or a $100-1,000$-fold molar excess of sIL-1RII relative to IL-1 $\beta$ completely inhibits IL-1 $\beta$ activity (as assessed from IL-1 $\beta$ - induced IL-8 release). In consequence, the present data 
suggest that, under "normal" conditions, HAECs exert an "anti-inflammatory" bias in the mucosa, at least as regards the IL-1 $\beta$ family.

TNF- $\alpha$ increased the release of all three cytokines (IL-1 $\beta$, IL-1RA and sIL-1RII). Interestingly, however, the TNF- $\alpha$ responses of the three cytokines differed. In the case of IL-1 $\beta$, the increases were progressive over the entire range of TNF- $\alpha$ concentrations. In contrast, increases in IL-1RA and sIL1 RII were maximal at $20 \mathrm{ng} \cdot \mathrm{mL}^{-1} \mathrm{TNF}-\alpha$. Furthermore, TNF- $\alpha$-induced increases in IL- $1 \beta$ release were proportionately greater than those in IL-1RA and sIL-1RII. It is of note in this regard that TNF- $\alpha$ concentrations in bronchoalveolar lavage fluid correlate with the severity of airway obstruction in subjects with asthma [1]. Accordingly, these data suggest that, under the conditions which exist in asthma, HAECs may promote inflammation in response to TNF- $\alpha$ by releasing disproportionately greater amounts of IL- $1 \beta$ than of IL-1RA and sIL-1RII. Furthermore, agents which increase cAMP production (e.g. $\beta_{2}$-adrenergic bronchodilators and prostaglandin $\left.\mathrm{E}_{2}\left(\mathrm{PGE}_{2}\right)\right)$, which would stimulate IL-1 $\beta$ release while inhibiting IL-1RA and sIL-1RII release, would add to this effect. It is of interest in this regard that IL-1 $\beta$ induces expression of phospholipase $\mathrm{A}_{2}$ and $\mathrm{PGE}_{2}$ production in HAECs [24]. $\mathrm{PGE}_{2}$, in turn, strongly stimulates cAMP production in HAECs, suggesting that an autocrine selfamplifying loop exists [25]. This amplification loop may contribute to the exponential increase in IL-1 $\beta$ release observed with increasing TNF- $\alpha$ concentration [25]. Finally, nitric oxide-induced increases in intracellular cGMP would tend to reduce IL-1RA and sIL-1RII levels relative to IL-1 $\beta$.

Increases in cAMP concentration augmented constitutive and TNF- $\alpha$-induced IL- $1 \beta$ release but inhibited IL-1RA and sIL-1RII release. PKA-dependent pathways were entirely responsible for the IL-1 $\beta$ response to dibutyryl cAMP, as evidenced by the fact that the specific PKA inhibitor, KT 5720, completely reversed this effect. However, KT 5720 did not reverse the dibutyryl cAMP effects on IL-1RA and sIL1RII, suggesting that PKA-independent pathways control the release of these cytokines.

In contrast to the response to dibutyryl cAMP, 8-bromocGMP had no effect on IL-1 $\beta$ release, but inhibited constitutive and TNF- $\alpha$-induced release of IL-1RA and sIL-1RII. KT 5823 inhibited the effects of 8-bromo-cGMP on IL-1RA, suggesting that PKG-dependent pathways control release of IL-1RA and sIL-1RII. Conversely, effects of 8-bromo-cGMP on sIL-1RII release were not altered by KT 5823, indicating that PKG-independent pathways control the release of sIL-1RII.

\section{Comparison with previous studies}

Prior studies have demonstrated release of IL-1 $\beta$ by HAECs in response to nitrogen dioxide and diisocyanate $[26,27]$, and release of IL-1RA in response to IL-4, IL-13 and interferon- $\gamma[22,28]$. Coulter et al. [23] demonstrated that HAECs and human alveolar epithelial (A549) cells both produce IL-1RA. It is of interest that IL-1RA release by HAECs was $\sim 60$-fold higher than that from alveolar epithelial cells.

In contrast to the present results, however, COULTER et al. [23] failed to detect sIL-IRII or the corresponding messenger ribonucleic acid in HAECs or A549 cells. The differing results obtained in the present study and that of COULTER et al. [23] are difficult to explain. However, differences in cell culture conditions may have contributed to the differing results obtained. For example, Coulter et al. [23] appear to have grown human epithelial cells on tissue culture plastic. The present cells were grown on a collagen matrix which stimulates the production and release of IL-1 $\beta$ and IL-1RA by cultured human blood mononuclear cells [29]. Growing cells on a collagen substrate could conceivably also have stimulated sIL-1RII expression in HAECs in the present study.

The present data on the effects of TNF- $\alpha$ and cAMP on IL-1 $\beta$ cytokine family member release by HAECs are compatible with data obtained in other cell systems. For example, in lipopolysaccharide-stimulated human promyelocytes, increases in intracellular cAMP levels enhance transcription and release of IL-1 $\beta$ [30]. Similar results have been obtained in rat hypothalamic microglia [31]. It is of interest that the effects of cAMP on IL-1 $\beta$ release are cell type-dependent, however. For example, increases in cAMP or stimulation with $\beta$-adrenergic agonists inhibit IL-1 $\beta$ production in human blood monocytes, mouse peritoneal macrophages and hypothalamic astrocytes [14, 15, 31].

\section{Conclusion}

In summary, the results of the present study demonstrate that release of interleukin-1 $\beta$, interleukin-1 receptor antagonist and soluble interleukin-1 receptor type II by human airway epithelial cells is: 1) constitutively biased towards greater release of inhibitors relative to interleukin-1 $\beta ; 2$ ) enhanced by tumour necrosis factor- $\alpha$; and 3 ) differentially affected by tumour necrosis factor- $\alpha$, cyclic adenosine monophosphate and cyclic guanosine monophosphate such that the ratio of inhibitors to interleukin- $1 \beta$ is reduced.

\section{References}

1. Barnes PJ, Chung KF, Page CP. Inflammatory mediators and asthma. Pharmacol Rev 1988; 40: 49-84.

2. Chung KF, Barnes PJ. Cytokines in asthma. Thorax 1999; 54: 825-857.

3. Broide DH, Lotz M, Cuomo AJ, Coburn DA, Federman EC, Wasserman SI. Cytokines in symptomatic asthma airways. J Allergy Clin Immunol 1992; 89: 958-967.

4. Jarjour NN, Busse WW. Cytokines in bronchoalveolar lavage fluid of patients with nocturnal asthma. Am J Respir Crit Care Med 1995; 152: 1474-1477.

5. Sousa AR, Lane SJ, Nakhosteen JA, Lee TH, Poston RN. Expression of interleukin-1 beta (IL-1 $\beta$ ) and interleukin-1 receptor antagonist (IL-1ra) on asthmatic bronchial epithelium. Am J Respir Crit Care Med 1996; 154: 1061-1066.

6. Ackerman VM, Marini E, Vittori A, Bellini A, Vassali G, Mattoli S. Detection of cytokines and their cell sources in bronchial biopsy specimens from asthmatic patients. Relationship to atopic status, symptoms, and level of airway hyperresponsiveness. Chest 1994; 105: 687-696.

7. Borish L, Mascali JJ, Dishuck J, Beam WR, Martin RJ, Rosenwasser LJ. Detection of alveolar macrophage-derived IL-1 $\beta$ in asthma. Inhibition with corticosteroids. J Immunol 1992; 149: 3078-3082.

8. Dinarello CA. Biologic basis for interleukin-1 in disease. Blood 1996; 87: 2095-2147.

9. Rosenwasser LJ. Biologic activities of IL-1 and its role in human disease. J Allergy Clin Immunol 1998; 102: 344-350.

10. Levine SJ, Larivée P, Logun C, Angus CW, Shelhammer JH Corticosteroids differentially regulate secretion of IL-6, IL-8 and GM-CSF by a human bronchial epithelial cell line. Am J Physiol Lung Cell Mol Physiol 1993; 265: L360-L368.

11. Marini M, Soloperto M, Mezzetti M, Fasoli A, Mattoli S. Interleukin-1 binds to specific receptors on human bronchial epithelial cells and upregulates granulocyte/macrophage 
colony-stimulating factor synthesis and release. Am J Respir Cell Mol Biol 1991; 4: 519-524.

12. Schmidt JA, Mizel SB, Cohen D. Interleukin-1, a potential regulator of fibroblast proliferation. J Immunol 1982; 128: 2177-2182.

13. Kelsen SG, Anakwe OA, Aksoy MA, Reddy PJ, Dhanesekaran ND. Interleukin-1 $\beta$ alters $\beta$-adrenergic receptor-adenylyl cyclase system function in human airway epithelial cells. Am J Physiol Lung Cell Mol Physiol 1997; 273: L694-L700.

14. Brandwein SR. Regulation of interleukin 1 production by mouse peritoneal macrophages. Effect of arachidonic acid metabolites, cyclic nucleotides, and interferon. $\mathrm{J}$ Biol Chem 1986; 261: 8624-8632.

15. Knudsen PJ, Dinarello CA, Strom TB. Prostaglandins post-transcriptionally inhibit monocyte expression of interleukin-1 activity by increasing intracellular cyclic adenosine monophosphate. J Immunol 1986; 137: 3189-3194.

16. Aaron SD, Angel JB, Lunau M, et al. Granulocyte inflammatory markers and airway infection during acute exacerbation of chronic obstructive pulmonary disease. $\mathrm{Am}$ J Respir Crit Care Med 2001; 163: 349-355.

17. Soler N, Ewig S, Torres A, Filella X, Gonsalez J, Zaubert A. Airway inflammation and bronchial microbial patterns in patients with stable chronic obstructive pulmonary disease. Eur Respir J 1999; 14: 1015-1022.

18. Orlando S, Sironi M, Bianchi G, et al. Role of metalloproteinases in the release of the IL-1 type II decoy receptor. J Biol Chem 1997; 272: 31764-31769.

19. Giri JG, Robb R, Wong WL, Horuk R. HepG2 cells predominantly express the type II interleukin-1 receptor (biochemical and molecular characterization of the type I receptor). Cytokine 1992; 4: 18-23.

20. McMahan CJ, Slack JL, Mosley B, et al. A novel IL-1 receptor, cloned from $\mathrm{B}$ cells by mammalian expression, is expressed in many cell types. EMBO J 1991; 10: 2821-2823.

21. Haskill S, Martin G, Van Le L, et al. cDNA cloning of an intracellular form of the human interleukin 1 receptor antagonist associated with epithelium. Proc Natl Acad Sci U S A 1991; 88: 3681-3685.
22. Levine SJ, Benfield T, Shelhammer JH. Corticosteroids induce intracellular interleukin-1 receptor antagonist type I expression by a human airway epithelial cell line. Am J Respir Cell Mol Biol 1996; 15: 245-251.

23. Coulter KR, Wewers MD, Lowe MP, Knoell DL. Extracellular regulation of interleukin (IL)-1 $\beta$ through lung epithelial cells and defective IL-1 type II receptor expression. Am J Respir Cell Mol Biol 1999; 20: 964-975.

24. Lin L-L, Lin AY, DeWitt DL. Interleukin-1 $\beta$ induces the accumulation of cytosolic phospholipase $\mathrm{A}_{2}$ and the release of prostaglandin $\mathrm{E}_{2}$ in human fibroblasts. J Biol Chem 1992; 267: 23451-23454.

25. Penn RB, Kelsen SG, Benovic JL. Regulation of the betaadrenergic receptor-adenylyl cyclase system in a human airway epithelial cell line. Am J Respir Cell Mol Biol 1994; 11: 496-505.

26. Devalia JL, Campbell AM, Sapsford RJ, et al. Effect of nitrogen dioxide on synthesis of inflammatory cytokines expressed by human bronchial epithelial cells in vitro. Am J Respir Cell Mol Biol 1993; 9: 271-278.

27. Mattoli S, Colotta F, Fincato G, et al. Time course of IL-1 and IL-6 release in human bronchial epithelial cell cultures exposed to toluene diisocyanate. J Cell Physiol 1991; 149: 260-268.

28. Levine SJ, Wu T, Shelhammer JH. Extracellular release of the type I intracellular IL-1 receptor antagonist from human airway epithelial cells. J Immunol 1997; 158: $5949-5957$.

29. Graves KL, Roman J. Fibronectin modulates expression of interleukin-1 $\beta$ and its receptor antagonist in human mononuclear cells. Am J Physiol 1996; 271: L61-L69.

30. Hurme M, Serkkola E, Ronni T, Silvennoinen O. Control of interleukin- $1 \beta$ expression by protein kinase $\mathrm{C}$ and cyclic adenosine monophosphate in myeloid leukemia cells. Blood 1990; 76: 2198-2203.

31. Tomozawa Y, Yabuuchi K, Inoue T, Satoh M. Participation of cAMP and cAMP-dependent protein kinase in $\beta$ adrenoceptor-mediated interleukin-1 $\beta$ mRNA induction in cultured microglia. Neurosci Res 1995; 22: 399-409. 